\title{
Girolamo Fracastoro and the Origin of the Etymology of Syphilis
}

\section{Luiz Alberto Peregrino Ferreira', Mariano Barthe Dupont ${ }^{2}$, Gerolamo Fracastoro ${ }^{3}$, Maurizio Rippa Bonati ${ }^{4}$}

\author{
${ }^{1}$ Departamento de Análises Clínicas, Centro de Ciências da Saúde, Universidade Federal de Santa Catarina, \\ Florianópolis, Brasil \\ ${ }^{2}$ Independent Translator, Florianópolis, Brasil \\ ${ }^{3}$ Scuola di Medicina e Chirurgia, Università Degli Studi di Verona, Verona, Italia \\ ${ }^{4}$ Dipartimento di Scienze Cardiologiche, Toraciche e Vascolari, Università Degli Studi di Padova, Padova, Italia \\ Email: peregrino.ferreira@ufsc.br, marianobarthe@yahoo.com.br, gerolamo56@gmail.com,maurizio.rippabonati@unipd.it
}

How to cite this paper: Ferreira, L. A. P. Dupont, M. B., Fracastoro, G., \& Bonati, M. R. (2017). Girolamo Fracastoro and the Origin of the Etymology of Syphilis. Advances in Historical Studies, 6, 104-112. https://doi.org/10.4236/ahs.2017.63008

\section{Received: July 27, 2017}

Accepted: September 18, 2017

Published: September 21, 2017

Copyright $\odot 2017$ by authors and Scientific Research Publishing Inc. This work is licensed under the Creative Commons Attribution International License (CC BY 4.0).

http://creativecommons.org/licenses/by/4.0/

\begin{abstract}
In 1530, Girolamo Fracastoro, an illustrious Italian physician and poet, published a book about a disease that was then known as the "French disease", which he named syphilis. Fracastoro's book, Syphilis sive morbus Gallicus, was written as a poem in hexameters verses, using figures from Greek mythology that provided facts about the Spanish discovery of the New World in 1492. A thorough literature review of the historical facts and mythological figures mentioned in Fracastoro's book enabled us to complete an in-depth analysis of the poem and understand some its smallest details. Hence, we propose a new hypothesis that the origin of the term Syphilis is based on the name Sypilus as well as the appearance of people who suffer from the disease.
\end{abstract}

\section{Keywords}

Girolamo, Fracastoro, French Disease, Syphilis, New World

\section{Introduction}

In 1530, Girolamo Fracastoro published one of his masterpieces, Syphilis sive morbus Gallicus (Syphilis or the French disease). Written in three books as a poem and in the text used 1300 hexameter verses to describe the details of the disease known as the "French disease." In the third book, Fracastoro told the story of a shepherd named Syphilus, who was the first person to have the disease that he would name syphilis (Fracastorii, 1530).

Currently, there are two main hypotheses about the origin of the disease's 
name: one hypothesis claims that the term was derived etymologically from the Greek expression meaning "friend of pigs"; the other hypothesis is based on the mythological name Sypilus, the son of Niobe, who was mentioned in a poem written by the Roman poet Ovid (Catellani \& Console, 2008).

However, by studying the voyages of Christopher Columbus in 1492, which were described by Pietro Martire d'Anghiera and Gonzalo Fernández de Oviedo y Valdés, and cited in Fracastoro's poem, we discovered a relationship between this historical event and Fracastoro's poem about the disease.

Indeed, in light of the knowledge of historical facts and an analysis of the mythological stories mentioned by Fracastoro, a more detailed reading of the poem allowed us to formulate a new hypothesis concerning the origin of the disease's name, Syphilis.

\section{About Girolamo Fracastoro}

Girolamo Fracastoro (Pellegrini, 1948; Pastore \& Peruzzi, 2006; Martellozzo, 1982; Simeoni, 1953) was born in Verona, although existing records do not establish the exact year of his birth. He studied at the University of Padua and received his degree in Artium on November 5, 1502. At this time, the same university hired him to be a Professor of Logic. In approximately 1505, Fracastoro graduated with a degree in medicine. He returned to Verona in 1509.

Following the publication of Syphilis sive morbus Gallicus, Fracastoro also published Homocentrica, which was about the movement of the stars (1538), De sympathia et antipathia rerum liber unus, which was a book on sympathy and antipathy of things, and De contagione et contagiosis morbis libri III (1546), which was about infection, the transmission of diseases and their cures.

After his death, Fracastoro's entire work (Opera Omnia) was published in 1555, including his unpublished philosophical treatises entitled Naugerius sive de Poetica dialogus (Naugerius or dialogue on the poetic), Turrius sive de intellectione dialogus (Turrius or dialogue on the intellection), and Fracastorius sive de anima dialogus (Fracastoro or dialogue on the soul).

\section{The Discoveries of Columbus and Fracastoro's Poem}

In his poem about syphilis, Fracastoro presented several facts related to the discoveries of Christopher Columbus. Several essays that were written by explorers about the discovery of the new lands were quite detailed, although they were not always published, and some were printed many years after they were written. The discovery of the Indies (now known as the Americas), including the islands and the continents, was reported by Diego Alvarez Chanca, a medical doctor of the Spanish Court who accompanied Columbus on his second trip in 1493, as well as PietroMartire d' Anghiera and Gonzalo Fernandez de Oviedo y Valdés (Gallinari, 1992; Angleria, 1537; Valdés, 1526).

In Venice, Giambattista Ramusio wrote in Italian three books about the reports of several captains, sailors and travelers in close collaboration with his 
Italian friends, including the Gasparo Contarini, Andrea Navagero, Pietro Bembo, Girolamo Fracastoro, Pietro Martire, as well as Oviedo (Ramusio, 1568, 1583, 1606; Del Piero, 1902; Milanesi, 1985).

In addition to his observations about the fauna, flora, and habits of the people, Pietro Martire also recounted a fascinating story of the natives of the "Spanish island" regarding their belief about the origins of men in the world. According to the story, the island had two caves where all of the people lived. They were forbidden by the God Sun to leave the caves. To ensure that no one would leave, the caves were watched by a guard. One day, the guard went for a walk around the island and failed to return before sunrise. As a punishment, he was transformed, by the God Sun, into a rock. On another night, many men left the caves and also did not return before sunrise, so they were all transformed into trees that were scattered throughout the island (Ramusio, 1606).

However, many still remained in the caves, including a man named Vaguoniona, an old inhabitant who had many children. One day he sent one of his sons out, but as a punishment from the Sun, his boy was transformed into a nightingale. Later, Vaguoniona sent out of the cave all of the women who had children to find his beloved son, and they were all turned into frogs. When Vaguoniona began to wander around the island, by the Sun's grace, he was never transformed and remained a human for the rest of his life (Ramusio, 1606).

4. The Mythology (Buxton, 2009; Butler, 2009; 0'Connell, 2010; Colección Carrascalejo de la Jara, 2004; Wilson, 2010; See, 2014)

In addition to his reports about the New World, Fracastoro used his vast knowledge of Greek mythology to write his poem, referring to local names and many episodes that were described by ancient Greek poets. In the following section, several details related Greek mythology that were cited by Fracastoro will be described. Further, these details will be associated with the poem and the historical facts of Columbus' New World discovery.

The current Turkish province of Manisa takes its name from the ancient city name Magnesia ad Sipylum due to its proximity to Mount Sipylus, where there is a rock that resembles a face. This rock was believed to be Niobe, a mythological character who was transformed into a rock. Niobe was the daughter of Tantalus, King of Tantalis city, which was also known as Sipylus. There are similarities between the stories of Atlantis and ancient Tantalis, as well as between Atlas and Tantalum.

It was Tantalus who cut his son, Pelops, into pieces, offering them to the Gods at a banquet. When it was served to them, the goddess Persephone absently ate part of Pelops' shoulder. As punishment, Tantalus was thrown into Tartarus, the deepest hell, where, as a torment for him, he was surrounded by food and water without being able to touch them.

The daughter of Tantalus, Niobe, insulted the goddess Leto (Latona to the 
Romans) and was harshly punished by Leto's offspring, Artemis and Apollo (the God Sun for the poets), with the death of all of her children. One of Niobe's murdered sons was named Sipylus.

Another character in Greek mythology mentioned in Fracastoro's poem is Phyllis, a young woman who espoused Demophonte, son of Theseus. One day, Demophonte traveled to Cyprus, but he did not return. Out of despair, Phyllis hanged herself and was transformed into an almond seed. After a long time, Demofonte returned and wept on Phyllis tomb, causing the seed to grow into an almond tree.

\section{The Poem}

As already mentioned, Fracastoro showed in his poem that he possessed a lot of knowledge about the Spanish discovery of the "New World", the lives of the native populations, and the disease that was then known as the "French disease."

In Book I, he referred to the discovery of the new land, mentioning the name of what would be the main island for the Spanish: "Hac ignota tenus, tractu iacet insula longo: Hispanam gens inventrix cognomine dixit." ("There is in a great distance an island unknown until now, called Spanish by the people who discovered it.")

In Book III described a land where cannibals lived: "Linquitur incerto fluitans Anthylia ponto, atque Hagia, atque alta Ammerie, execrataque tellus cannibalum." ("They leave behind Anthylia floating in the fickle sea, Hagia, the high Ammeria, and the accursed land of cannibals.")

Fracastoro referred to the Spaniards' navigation from the Iberian coast and their discovery of new lands, where there was "some disease" that afflicted almost the entire population. However, he questioned the reasoning that the contagion of Europeans was due to their coexistence with the natives.

"Num tempore ab illo vecta mari occiduo, nostrum pervenit in orbem: ex quo lecta manus solvens de littore Ibero ausa fretum tentare, vagique incognita ponti est aequora: et orbe alio positas perquirere terras? Illic namque ferunt, aeterna labe per omnes id morbi regnare urbes, passimque vagari perpetuo coeli vitio: atque ignoscere paucis. Commercine igitur causa accessisse putandum est delatam contagem ad nos: quae parva sub ipsis principiis, mox et vires et pabula sensim suscipiens, sese in terras diffuderit omnes?"

"Do not come at that time to our brought world (referring to the disease) from the western sea, in the event that a selected group, departed from the Iberian coast, dared to venture into the sea, out in the unknown ocean waters in search of land situated in another orbe? Therefore they say that there reigns such a disease passing to eternal scourge in every city, wandering everywhere because of a perpetual habit of heaven and forgiving few. We should not think, then, that it was because of the address with those people that came brought the contagion to us, which, being small at first, then gradually gaining forces and food, has spread throughout the lands?" 
Fracastoro noted that the disease had already existed in various regions of the world, but until that time, it had no name. In our understanding, this demonstrates his concern about this fact.

“...quamquam nobis nec nomine nota hactenus illa fuit: quoniam longaeva vetustas cuncta situ involvens, et res, et nomina delet: nec monumenta patrum seri videre nepotes."

“... Although it (the disease) was not known to us with a name so far: because the long-lived antiquity, involving all with its mold, destroys things, and names, and does not see the grandchildren that come later, what it is worth remembering left by the parents."

Further, Fracastoro described some of the disease's clinical features, such as the mucus in the lesions, which appeared scattered throughout the patient's body.

"Protinus informes totum per corpus achores rumpebant: faciemque horrendam, et pectora foede turpabant: species morbi nova: pustula summae glandis ad effigiem, et pituita marcida pingui. Tempore quae multo non post adaperta dehiscens, mucosa multum sanie, taboque fluebat."

"Throughout the body disgusting and deforming ulcers soon broke out, disfiguring the face in a horrible way and also damaging the chest: a new form of this disease, with pustules with thick mucus. Which not long after, opened up cracking, and from there flowed an amount of mucus with pus and rot".

\section{The Poem's Content and the Disease's Name}

It is worth noting that Fracastoro had vast knowledge of classical languages (Greek and Latin), classic literature, mythology, geography, medicine, astronomy, the arts, and science in general, as well as a concern about creating a name to identify the disease.

In the poem, Fracastoro changed a few words in a very subtle way so that only attentive readers could realize the changes. For example, i) Ophyre was changed, with the intentional alteration of the biblical Ophir, the land of gold; ii) Anthylia was the name given to the Caribbean Antilles islands; iii) Gyane island replaced Juana island, which was named thus by Christopher Columbus; and iv) Ammeria, in reference to America, was changed due to was the name given to the Indias by Martin Waldseemüller's world map in 1507.

In Book I, after describing the clinical features of the disease, Fracastoro wrote about the Phyllis tree in exactly five lines after, pointing out the relationship between the nodes of the almond tree and the lesions caused by the disease.

"Tum saepe aut cerasis, aut Phyllidis arbore tristi, vidisti pinguem ex udis manare liquorem corticibus: mox in lentum durescere gummi. Haud secus hac sub labe solet per corpora mucor diffluere: hinc demum in turpem concrescere callum."

"You must have seen too often that, as the humid cortices of the cherry or the sad Phyllis tree exudes a thick liquid, which then hardens and becomes a viscous 
gum. It is no different from this disease that pours mucus in the body and, from there, finally grows in the form of an ugly callus (node)."

In Book III, Fracastoro described the origin of the disease and also created a new name for it-syphilis. In the beginning, he described a ceremony among the natives and the sick individuals who were witnessed by the Spanish. The chief of the tribe and Columbus were present at this ceremony. According to the author's description, they were already able to understand each other and communicate: "Ipsi inter sesereges in littore laeti complexu iungunt dextras, et foedera firmant." ("The Kings gladly narrowed their right hand on the beach and confirmed the covenant.")

At the ceremony, the natives killed various types of animals, eating their meat and viscera; and the medicine man used a leaf branch to spread a liquid all over the body of the wounded, including the lesions, to cure them of the disease. This liquid was made from cooked leaves and the stem of a plant called guaiacum.

Amazed, Columbus, the "King" of the Spaniards, asked why such a ceremony was held. Therefore, the native "King" began to tell him about the origin of his people: "Forsitan Atlantis vestras pervenit ad aures nomen, et ex illo generis long ordine ducti. Hac et us long series of Stirpe profecti Dicimur." ("Perhaps the name of Atlantis has reached your ears, from Atlas whom a lineage continues through a long succession. It is also said about us that we proceed by a long series from this breed.")

And then, the native "King" described where they lived during ancient times. Because of lust, they were punished by an avenging God: "ingenti terrae concussa Atlantia motu corruit, absorpta ocean" ("then Atlantia was hit by a very strong earthquake and destroyed, sinking in the ocean”).

The native King explained to Columbus that the disease was also a punishment, which referred to a shepherd named Syphilus. It was Syphilus who made offerings to a mortal, King Alcitoo, to try to make him equal to Apollo (the Sun God). Syphilus was punished as the first to have the disease. However, he was spared and did not die as a result of it. Speaking on behalf of the Sun God, it was the nymph Ammerice who warned that evil (the disease) would be eternal. She said all people born in that land would have the disease, and she explained what type of offerings should be made. Thus, as a reminder, the ancestors of the natives created an annual rite such as the one that was witnessed by the "Spanish King."

\section{The Relationship between Beliefs of the Natives of the New World, Greek Mythology and Fracastoro's Poem}

In the tale told by the natives, all of the men who fled the caves were punished by the Sun God. In Fracastoro's poem, the same event occurred when the shepherd and other people were punished by Apollo for Syphilus' offense. Indeed, similar to Phyllis, who was transformed into an almond tree, the natives were transformed into trees. In addition, Fracastoro wrote that the sick people had lesions 
that made them appear similar to an almond tree.

As mentioned above, Vaguoniona, one of the inhabitants of the caves, left the cave but was never metamorphosed into anything; he lived wandering the lands as a human. Similarly, in the poem, Syphilus was spared because he was the first person to have the disease, but he did not die from it; however, he was doomed to see the suffering of all the natives.

Tantalum was the King of the city of Tantalis, also known as Sipylus, which disappeared like Atlantis, which Fracastoro cited as Atlantia at the beginning of the conversation between the native "King" and the Spanish "King." Tantalus had a daughter, Niobe, whose children were killed by Apollo, the Sun God, including her son named Sipylus.

Due to Niobe's great sorrow that was caused by the loss of her children, she was turned into a rock, just like the guardian of the caves in the history of the natives.

The rock that resembles Niobe's face is close to Mount Sipylus, which is located in the region of Turkey that is now known as Manisa. This city's name originated from the ancient toponym Magnesia ad Sipylum, named thus because it was next to the mountain.

Fracastoro, therefore, created the story about the origin of the natives, kept the god Sun as the punisher, and made several associations or correlations between Greek mythology and the natives' story narrated by the "King." By connecting the origin of the New World people with Atlas and Atlantis Fracastoro created a relation between the origin, Tantalus, Niobe and Sypilus. He also included the story of young Phyllis when he observed the similarity between lesions in the patients and the almond tree.

Thus, it was possible to find several similarities between classical literature, the stories collected and described by Pietro Mártire, and Fracastoro's poem. Therefore, we propose another hypothesis about the origin of the disease's name.

\section{Conclusion: The Origin of the Term Syphilis}

Understanding the facts presented in the poem made it possible to deduce how Fracastoro created a name for the disease in order for it to be easily identified.

Fracastoro searched for a character in a mythological world and found Sipylus. He made an analogy between the sick people and the almond tree, highlighting the fact that individuals sick with the disease resembled the tree into which Phyllis was transformed.

It is important to mention that although Fracastoro interchanged some letters in the names, he did it in such a way that readers could deduce the origin of the name that he created.

Our understanding is that, to create a name for this disease, Fracastoro invented a story that was inspired by SIPYLUS and included PHYLLIS to express the appearance of the disease: SIPYLUS + PHYLLIS = SIPHYLLIS. Then, to keep the euphony, he switched the letter "I" for "Y" and vice versa, withdrew one let- 
ter "L" and created the name of the disease, SYPHILIS. The two last letters, "IS," are commonly used for disease designation. After gave a name for the shepherd and created the name SYPHILUS. Hence, those who knew these mythological characters could understand to whom Fracastoro referred.

Fracastoro probably intended to create the word Syphilis to avoid terms such as the "French disease," "Italian evil," "Napolitan evil," and so many other designations that have been given to the terrible disease. He created a new character, Syphilus, and made his home Atlantis, a lost continent, so that any people could not be accused of spreading the contagion.

Even today, as Fracastoro wished, the disease is called syphilis.

\section{References}

Angleria, P. M. (1537). De rebus oceanicis et \& Orbe novo decades três (pp. 1-214). Basilea. https://www.bsb-muenchen.de/index.php

Butler, S. H. (2009). Iliad. The Floating Press, 1-622.

http://site.ebrary.com/lib/buufsc/detail.action?docID=10808275\&p00=greek+mythology

Buxton, R. (2009). Forms of Astonishment: Greek Myths of Metamorphosis (pp. 1-298). New York: Oxford University Press. http://site.ebrary.com/lib/buufsc/reader.action?docID=10348644\#

Catellani, P., \& Console, R. (2008). Girolano Fracastoro: Syphilis, Morbus Gallicus e il "Mal Francese": Ricerca di una cura per la sifilide. Memorie Scientifiche, Giuridiche, Letterarie. Acc Naz Sci Lett Arti di Modena (Vol. XI, Prima parte-Fasc. II): Cer. VIII.

Colección Carrascalejo de la Jara (2004). Santa Fé: Ovidio. http://site.ebrary.com/lib/buufsc/detail.action?docID $=10049228 \& p 00=$ ovidio

Del Piero, A. (1902). Della Vita e degli studi di Giovanni Battista Ramusio. Venezia: Prem. Stabilimento Tip.-Lit. Visentini Cav. Federico.

Fracastorii, H. (1530). Syphilis Sive Morbus Gallicus. Verona: [Unknown Publisher].

Gallinari, L. (1992). Diego Alvarez Chanca médico di Cristoforo Colombo. Cagliari: Edizioni Universitarie della Sardegna.

Martellozzo, E. (1982). Acta Graduum Academicorum Gymnasii Patavini: Ab Anno 1501 ad annum 1550: Indexnominum cum aliis actibus praemissis. Padova: Antenore (Vol. XXVII).

Milanesi, M. (1985). Navigazioni e Viaggi (Volume Primo). Torino: Giulio Euinaudi Editore.

O’Connell, T. (2010). Atlantipedia. Dublin: A Mifsud. http://site.ebrary.com/lib/buufsc/detail.action?docID $=10835245 \& \mathrm{p} 00=$ atlantis

Pastore, A., \& Peruzzi, E. (2006). Girolamo Fracastoro: Framedicina, filosofia e scienzedellanatura. Firenze: Leo S. Olschki.

Pellegrini, F. (1948). Fracastoro (Monografia; n. 3). Trieste: Zigiotti.

Ramusio, G. B. (1568). Dellenavigationietviaggi (3th ed., Primo Volume). Venezia: Stamperia de Giunti. https://www.bsb-muenchen.de/index.php

Ramusio, G. B. (1583). Delle navigationi et viaggi (Secondo Volume). Venezia: Stamperia de Giunti. https://www.bsb-muenchen.de/index.php

Ramusio, G. B. (1606). Dellenavigationietviaggi (Volume Terzo). Venezia: Stamperia de Giunti, 35 back. https://www.bsb-muenchen.de/index.php 
See, S. (2014). The Greek Myths. Hong Kong: S\&T.

https://books.google.com.br/books?id=onDwBQAAQBAJ\&hl=pt-BR\&source=gbs_nav links_s

Simeoni, L. (1953). Studi Storici Veronesi (Volume 4). Verona: Presso la direzione della revista.

Valdés, G. F. de O. y. (1526). Oviedo dela natural hystoria delas Indias. pp. 1-106. http://www.wdl.org/pt/item/7331/

Wilson, E. S. (2010). Six Tragedies. New York: Oxford University Press. http://site.ebrary.com/lib/buufsc/detail.action?docID=10365183\&p00=tantalus

Submit or recommend next manuscript to SCIRP and we will provide best service for you:

Accepting pre-submission inquiries through Email, Facebook, LinkedIn, Twitter, etc. A wide selection of journals (inclusive of 9 subjects, more than 200 journals)

Providing 24-hour high-quality service

User-friendly online submission system

Fair and swift peer-review system

Efficient typesetting and proofreading procedure

Display of the result of downloads and visits, as well as the number of cited articles Maximum dissemination of your research work

Submit your manuscript at: http://papersubmission.scirp.org/

Or contact ahs@scirp.org 